\title{
Deteksi dan Klasifikasi Sinyal Listrik Non-Stasioner yang Mengandung Masalah Kualitas Daya Menggunakan Transformasi Hilbert Huang
}

\author{
Mohammad Jasa' Afroni ${ }^{1}$, Oktriza Melfazen ${ }^{1)}$ \\ ${ }^{1)}$ Program Studi Teknik Elektro, Fakultas Teknik, Universitas Islam Malang \\ Email: myasa69@gmail.com, oktrizamelfazen@gmail.com
}

\begin{abstract}
Abstrak
Makalah ini menyajikan klasifikasi sinyal listrik non-stasioner yang mengandung masalah Kualitas Daya (KD) berbasis Transformasi Hilbert Huang (THH) dan Jaringan Saraf Tiruan (JST). Transformasi Hilbert Huang (THH) adalah metode analisis sinyal yang relatif baru, yang terdiri dari dua tahap - Dekomposisi Mode Empiris (DME) dan Transformasi Hilbert (TH). Proses DME menguraikan sinyal menjadi komponen - komponennya dalam bentuk Fungsi Mode Intrinsik (FMI) sementara TH digunakan untuk memperoleh amplitudo dan frekuensi sesaat dari masing-masing FMI.

Fitur yang diekstraksi melalui THH digunakan untuk melatih JST guna mengenali kelas sinyal yang diproses. Kelas sinyal yang diidentifikasi mulai dari sinyal normal, interupsi, sag, swell, harmonisa, transien, dan gabungannya.

Hasil simulasi menunjukkan bahwa kombinasi THH dan JST dapat secara efektif mendeteksi dan mengklasifikasikan sinyal yang mengandung berbagai masalah KD.
\end{abstract}

Kata Kunci - Dekomposisi Mode Empiris, Jaringan Saraf Tiruan, Klasifikasi Sinyal, Kualitas Daya, Transformasi Hilbert Huang.

\section{PENDAHULUAN}

Pertumbuhan penggunaan peralatan elektronika daya di sisi pelanggan, seperti misalnya komputer dan peralatan elektronik rumah tangga, sampai pada VSD (Variable Speed Drive) di industri telah menjadi sumber polusi Kualitas Daya (KD) yang menciptakan lingkungan kelistrikan yang buruk. Di sisi lain, penggunaan peralatan listrik sensitif yang dikendalikan oleh elektronika daya atau mikroprosesor telah meningkat dengan cepat. Bila tidak ada keseimbangan antara polusi kelistrikan dengan kemampuan peralatan sensitif untuk bertahan dalam lingkungan tersebut, banyak masalah kualitas daya dapat terjadi. Degradasi kualitas tenaga listrik biasanya disebabkan oleh gangguan saluran listrik seperti tegangan sag / swell dengan atau tanpa harmonisa, gangguan sesaat, distorsi harmonis, flicker, notch, spike dan transien. Sinyal listrik yang mengandung masalah kualitas daya ini dapat menyebabkan kegagalan, berkurangnya keandalan peralatan listrik dan pemadaman yang mahal di sisi pelanggan [1].

Untuk meningkatkan kualitas pelayanan listrik, masalah kualitas daya tersebut perlu diidentifikasi dengan tepat sebelum tindakan perbaikan yang sesuai dapat dilakukan. Oleh karena itu, pada paper ini dibahas 8 jenis sinyal gangguan yang mengandung masalah kualitas daya listrik (termasuk bentuk gelombang normal) yang sering terjadi pada jaringan distribusi. Salah satu isu penting dalam analisis kualitas daya adalah mendeteksi dan mengklasifikasikan gelombang gangguan secara otomatis dengan cara yang efisien. Untuk mendeteksi dan mengatasi masalah kualitas daya listrik, banyak perusahaan listrik melakukan pemantauan KD untuk pelanggan industri dan pelanggan penting yang lain.

Metode analisis sinyal konvensional yang paling populer adalah Transformasi Fourier (TF). Metode ini bekerja sangat baik bila digunakan pada sinyal periodik stasioner, tetapi tidak sesuai untuk sinyal non-stasioner yang memiliki frekuensi, amplitudo atau fasa bervariasi dari waktu ke waktu. Ini dikarenakan TF mengasumsikan sinyal yang ditinjau tidak berubah untuk interval $-\infty \leq \mathrm{t} \leq$ $\infty$. FFT (Fast Fourier Transform) adalah algoritma yang efisien untuk menghitung versi diskrit FT, yang sering disebut Discrete Fourier Transform (DFT), dan karenanya FFT tersebut tidak akurat untuk bentuk gelombang nonstasioner.

Beberapa teknik telah dikembangkan untuk membuat FFT dapat digunakan untuk bentuk gelombang non stasioner dengan menggunakan STFT (Short Term Fourier Transform), yang menggunakan teknik jendela bergerak sepanjang sumbu waktu untuk mengevaluasi FFT [2] pada area yang lebih kecil dari keseluruhan sinyal.

Metode analisis sinyal yang lain adalah Transformasi Wavelet (TW). Bila TF menganggap bahwa sinyal terdiri 
dari serangkaian gelombang sinusoidal dengan frekuensi yang berbeda, maka TW mengasumsikan sinyal terdiri

dari "wavelet", yang merupakan representasi skala dan pergeseran wavelet induk (mother wavelet) [3]. Berbeda dengan STFT yang menggunakan lebar jendela (window) yang tetap, TW menggunakan teknik windowing dengan ukuran jendela bervariasi. Oleh karena itu, dimungkinkan untuk memilih jendela waktu yang panjang untuk mendapatkan informasi sinyal frekuensi rendah yang lebih tepat atau jendela yang lebih pendek untuk analisis sinyal frekuensi tinggi [4]. Dengan teknik jendela yang fleksibel ini, TW dapat digunakan untuk menganalisis lokasi tertentu dari sinyal kompleks yang dikenal sebagai analisis lokal. Pilihan yang tepat dari wavelet induk dapat memungkinkan deteksi dan penentuan lokasi berbagai gangguan [5]. Namun, akurasi dekomposisi sinyal KD dipengaruhi secara signifikan oleh pilihan kelompok wavelet dan wavelet induk [3]. Sekali fungsi wavelet induk dipilih, fungsi tersebut harus digunakan untuk menganalisis semua data. Namun, karena sifat sinyal yang mengandung variasi amplitudo maupun frekuensi, pilihan lain dari wavelet induk mungkin diperlukan. Oleh karena itu, TW tidak dapat bekerja secara adaptif dalam analisis bentuk gelombang KD yang non-stasioner.

Di antara perkembangan terkini dari metode dekomposisi sinyal yang telah dilaporkan oleh para peneliti adalah Transformasi Hilbert Huang (THH) [6] yang sangat sesuai untuk menganalisis sinyal stasioner dan non-stasioner.

THH adalah metode adaptif yang juga dapat digunakan untuk menganalisis sinyal KD [7]. Dalam metode THH, sinyal pertama kali didekomposisi dengan menggunakan proses Dekomposisi Mode Empiris (DME) ke sejumlah Fungsi Mode Intrinsik (FMI) yang mengandung informasi frekuensi dan amplitudo.[8]. Transformasi Hilbert (TH) kemudian diterapkan pada setiap FMI untuk memperoleh nilai amplitudo dan frekuensi vs waktu sesaat [9].

II. TRANSFORMASI HILBERT HUANG (THH)

\section{A. Pengantar Transformasi Hilbert Huang}

THH terdiri dari dua proses yang berbeda. Pertama, sinyal yang akan dianalisis didekomposisi dengan menggunakan proses Dekomposisi Mode Empiris (DME) untuk memperoleh komponen sinyal dalam bentuk Fungsi Mode Intrinsik (FMI) yang mengandung informasi frekuensi dan amplitudo dari komponen tersebut [15]. DME menguraikan sinyal ke dalam bentuk FMI secara urut dari frekuensi tertinggi ke frekuensi terendah. Begitu sinyal terdekomposisi, Transformasi Hilbert (TH) kemudian dapat diterapkan ke setiap FMI untuk memperoleh amplitudo dan frekuensi sesaat vs. waktu. Kombinasi proses DME dan Transformasi Hilbert dikenal sebagai THH.

\section{B. Dekomposisi Mode Empiris (DME)}

Langkah pertama dalam algoritma $\mathrm{THH}$ adalah menguraikan sinyal $\mathrm{S}(\mathrm{t})$ ke dalam bentuk FMI melalui proses DME. Seiring dengan berlangsungnya proses dekomposisi, masing-masing FMI harus memenuhi persyaratan sebagai berikut [8]:

(a) Terdapat hanya 1 nol di antara dua titik ekstrim lokal yang berdekatan

(b) Nilai rata - rata lokal harus sama dengan nol

Langkah - langkah untuk menjalankan proses DME adalah sebagai berikut [10]:

1. Carilah maxima dan minima lokal dari sinyal $\mathrm{S}(\mathrm{t})$

2. Dengan menggunakan interpolasi kubik spline, hubungkan semua maxima untuk mendapatkan selubung maxima $\mathrm{C}_{\max }(\mathrm{t})$ dan hubungkan semua minima untuk mendapatkan selubung minimum $\mathrm{C}_{\min }(\mathrm{t})$.

3. Hitunglah rata - rata dari kedua selubung tersebut $\mathrm{C}_{\text {mean }}(\mathrm{t})=\left(\mathrm{C}_{\text {max }}(\mathrm{t})+\mathrm{C}_{\text {min }}(\mathrm{t})\right) / 2$

4. Hitung calon FMI pertama (fungsi proto mode, $\left.\mathrm{P}_{\mathrm{mfl}}(\mathrm{t})\right)$,

$\mathrm{P}_{\mathrm{mf1}}(\mathrm{t})=\mathrm{S}(\mathrm{t})-\mathrm{C}_{\text {mean }}(\mathrm{t})$

5. Periksa apakah $\mathrm{P}_{\mathrm{mf} 1}(\mathrm{t})$ memenuhi syarat untuk menjadi FMI, bila ya, maka FMI $\psi(t)=\mathrm{P}_{\mathrm{mfl}}(\mathrm{t})$. Bila tidak, ulang langkah $1-4$ pada $\mathrm{P}_{\mathrm{mf} 1}$ sehingga syarat menjadi FMI terpenuhi.

6. Hitung residu pertama $\mathrm{r}_{1}(\mathrm{t})$, $\mathrm{r}_{1}(\mathrm{t})=\mathrm{S}(\mathrm{t})-\psi(t)$

7. Periksa apakah amplitudo maksimum residu berada di bawah suatu ambang batas atau jumlah maksima atau minima kurang dari empat, jika betul maka hentikan proses DME, jika tidak, ulangi langkah 1 - 6 pada residu $\mathrm{r}_{1}(\mathrm{t})$.

Gbr 1 menunjukkan ilustrasi sederhana proses DME
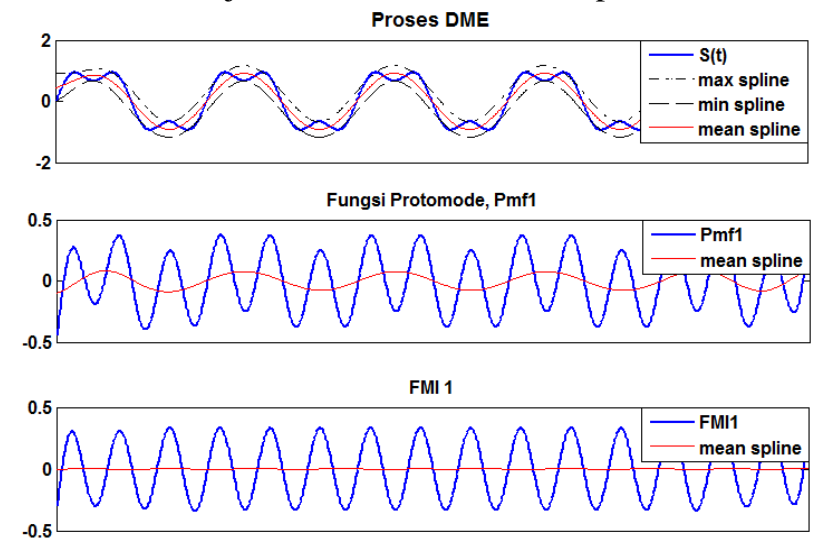

Gbr. 1 Proses DME dari sinyal sederhana, (a) Sinyal yang akan diproses berikut maxima dan minimanya, (b) Fungsi protomode pertama, (c) FMI pertama

Selubung - selubung maxima dan minima dari sinyal $\mathrm{S}(\mathrm{t})$ pertama kali diperoleh dengan menggunakan interpolasi spline kubik, rerata dari selubung ini kemudian dihitung dan dikurangkan dari $\mathrm{S}(\mathrm{t})$ yang menghasilkan $\mathrm{P}_{\mathrm{mfl}}$, ditunjukkan pada Gbr 1(b) yang masih belum memenuhi syarat sebagai FMI, karena rerata lokalnya tidak nol. Langkah-langkah di atas perlu diulang untuk memproses $\mathrm{P}_{\mathrm{mfl}}$ sehingga memenuhi syarat untuk menjadi FMI pertama. Setelah 5 iterasi, FMI pertama diperoleh seperti yang ditunjukkan pada Gbr 1 (c) di mana kondisi untuk menjadi FMI terpenuhi yaitu: (i) ada satu nol antara dua ekstrem lokal berurutan dan (ii) rerata lokal adalah nol.

Setelah semua FMI diperoleh, masing-masing FMI 
kemudian diproses menggunakan Transformasi Hilbert.

C. Transformasi Hilbert

Transformasi Hilbert dari suatu FMI $x(t)$ dengan variabel kontinyu t didefinisikan sebagai:

$$
H[x(t)]=\frac{1}{\pi} P \int_{-\infty}^{\infty} \frac{x(\tau)}{t-\tau} d \tau
$$

Dimana: P adalah integral nilai pokok Cauchy

Dapat ditunjukkan bahwa, Transformasi Hilbert dari suatu sinyal secara efektif menghasilkan sinyal ortogonal yang sudut fasanya bergeser sebesar 90 derajat dari sinyal asli.

Dengan mendefinisikan sebuah sinyal $\mathrm{z}(\mathrm{t})$ sebagai:

$$
z(t)=x(t)+H[x(t)]=x+j y=a(t) e^{j \theta(t)}
$$

Nilai frekuensi dan amplitudo $z(t)$ sesaat dapat dihitung sebagai berikut [9]:

Nilai Amplitude sesaat: $\quad a(t)=\sqrt{x^{2}+y^{2}}$

$$
\text { Nilai frekuensi sesaat: } \quad \omega(t)=\frac{d \theta}{d t}
$$

Dengan cara ini, TH dari FMI $\mathrm{x}(\mathrm{t})$, menghasilkan amplitudo dan frekuensi seketika. Namun, ini hanya berlaku jika FMI yang diwakili oleh $\mathrm{x}(\mathrm{t})$ adalah sinusoida murni dengan frekuensi tunggal.

\section{SINYAL MENGANDUNG HARMONISA}

Untuk menguji bagaimana DME bekerja dengan sinyal non-stasioner yang mengandung masalah $\mathrm{KD}$, DME diterapkan pada sinyal mengandung harmonisa yang terdiri dari dua segmen dengan kandungan komponen yang bervariasi seperti diberikan oleh (9):

$$
S(t)=\left\{\begin{array}{l}
\sin \left(2 \pi 50 t_{a}\right)+0.33 \sin \left(2 \pi 150 t_{a}\right), 0 \leq t_{a}<0.10 s \\
\sin \left(2 \pi 50 t_{b}\right)+0.2 \sin \left(2 \pi 250 t_{b}\right), 0.10 \leq t_{b}<0.2 s
\end{array}\right.
$$

FMI yang dihasilkan dari proses DME diberikan pada Gbr 2, sedangkan amplitude dan frekuensi sesaat yang diperoleh dari TH diberikan pada Gbr 3.

a)

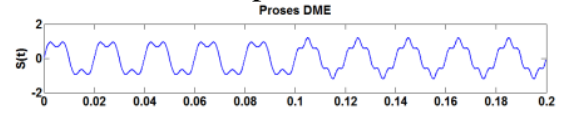

b)

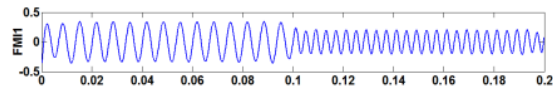

c)

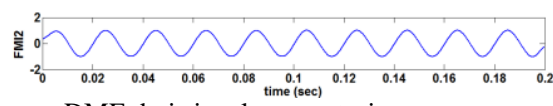

Gbr 2. Proses DME dari sinyal non - stasioner yang mengandung harmonisa (a) Sinyal asli S(t), (b) FMI1, (c) FMI2 Transformasi Hilbert $\mathbf{S}(\mathrm{t})$

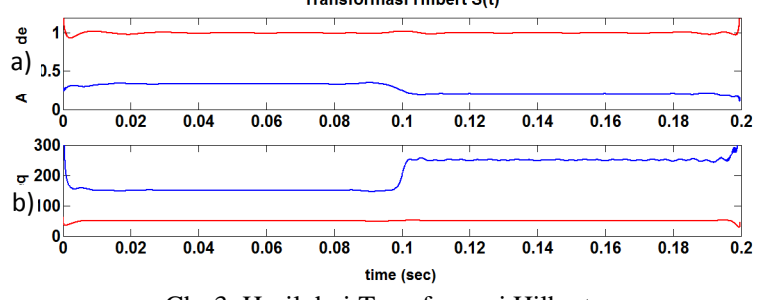

Gbr 3. Hasil dari Transformasi Hilbert:

(a) Amplitudo sesaat, (b) Frekuensi sesaat
IV. SINYAL MENGANDUNG HARMONISA DAN SAG

THH kemudian diaplikasikan pada sinyal yang mengandung gabungan antara harmonisa dan sag $\mathrm{S}_{\mathrm{A}}(\mathrm{t})$ sbb:

$$
S_{A}(t)=\left\{\begin{array}{c}
\sin \left(2 \pi 50 t_{a}\right)+0.2 \sin \left(2 \pi 250 t_{a}\right), 0 \leq t_{a}<0.1 s \\
0.8 \sin \left(2 \pi 50 t_{b}\right)+0.16 \sin \left(2 \pi 250 t_{b}\right), 0.1 \leq t_{b}<0.2 s \\
\sin \left(2 \pi 50 t_{c}\right)+0.2 \sin \left(2 \pi 250 t_{c}\right), 0.2 \leq t_{c}<0.3 \mathrm{~s}
\end{array}\right.
$$

FMI yang dihasilkan oleh proses DME terhadap sinyal yang diberikan pada (10) ditunjukkan pada Gbr 4, sedangkan nilai sesaat amplitudo dan frekuensi yang diperoleh melalui Transformasi Hilbert dari FMI tersebut ditunjukkan pada Gbr 5.

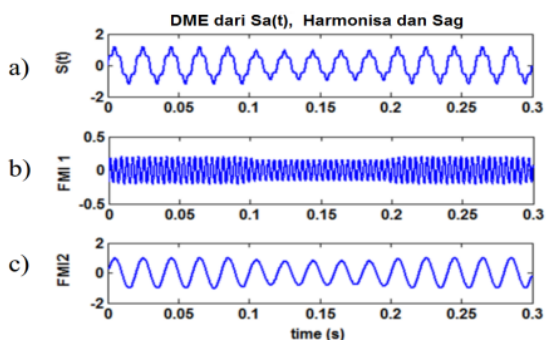

Gbr. 4 FMI dari Sinyal mengandung sag $\mathrm{S}_{\mathrm{A}}(\mathrm{t})$
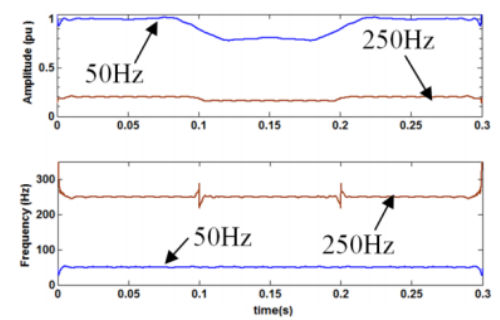

Gbr. 5 TH dari FMI sinyal $\mathrm{S}_{\mathrm{A}}(\mathrm{t})$

Tampak pada Gbr 5, bahwa metode THH dapat secara otomatis memperoleh nilai sesaat dari amplitudo dan frekuensi dari komponen - komponen sinyal nonstasioner.

\section{TEKNIK JENDELA}

Untuk menyederhanakan informasi yang diperoleh dari Transformasi Hilbert, sebuah teknik penyederhanaan fitur sinyal menggunakan Teknik Jendela digunakan dalam penelitian ini. Teknik ini menerapkan THH pada jendela geser (sliding window) sinyal $\mathrm{S}(\mathrm{t})$ untuk mengidentifikasi saat perubahan (batas - batas) sinyal non-stasioner. Setelah batas-batas teridentifikasi, THH kemudian dapat diterapkan pada setiap segmen (area antara dua batas) yang berisi bagian stasioner dari sinyal asli. Misalnya saja dipilih jendela berukuran 0,02 detik dan oleh karena itu THH diterapkan pada $\mathrm{S}(\mathrm{t})$ dari 0,0 sampai 0,02 detik, 0,02 - 0,04 detik dan seterusnya. Bila terjadi perubahan frekuensi atau amplitudo pada FMI pertama dari jendela tertentu, titik pertama jendela ditandai sebagai batas segmen sinyal. Untuk sinyal dengan harmonisa dan sag $\mathrm{S}_{\mathrm{A}}(\mathrm{t})$ di atas, saat perubahan ditemukan pada 0,1 detik dan 0,2 detik. Ketika batas semua segmen berhasil 
diidentifikasi, THH diterapkan pada setiap segmen untuk mendapatkan hasil yang lebih akurat.

Hasil teknik jendela untuk sinyal $\mathrm{S}(\mathrm{t})$ ditunjukkan pada Gbr 6 dan Tabel 1 yang menunjukkan bahwa titik perubahan pada nilai sesaat amplitudo dan frekuensi ditemukan dengan baik selama transisi dan hasil yang akurat diperoleh untuk masing-masing komponen pada masing-masing segmen dari sinyal nonstasioner.
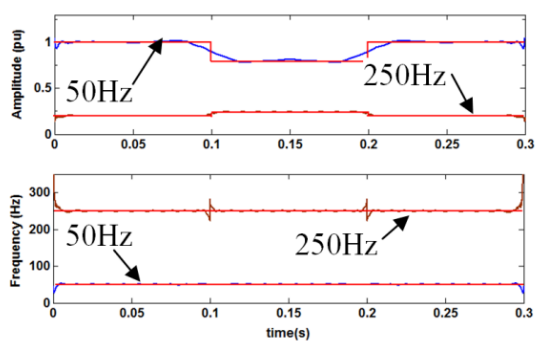

Gbr. 6 Hasil Teknik Jendela terhadap TH dari FMI sinyal $S_{\mathrm{A}}(\mathrm{t})$ (a). Amplitudo Sesaat, (b) Frekuensi sesaat

Tabel 1

Hasil Analisa Sinyal $\mathrm{S}_{\mathrm{A}}(\mathrm{t})$ menggunakan THH dan Teknik Jendela

\begin{tabular}{|c|c|c|c|c|c|}
\hline \multicolumn{2}{|c|}{$0 \mathrm{~s} \leq \mathrm{t}<0.1 \mathrm{~s}$} & \multicolumn{2}{c|}{$0.1 \mathrm{~s} \leq \mathrm{t}<0.2 \mathrm{~s}$} & \multicolumn{2}{c|}{$0.2 \mathrm{~s} \leq \mathrm{t} \leq 0.3 \mathrm{~s}$} \\
\hline $\begin{array}{c}\text { Amp } \\
\text { (p.u) }\end{array}$ & $\begin{array}{c}\text { Freq } \\
(\mathrm{Hz})\end{array}$ & $\begin{array}{c}\text { Amp } \\
(\mathrm{V})\end{array}$ & $\begin{array}{c}\text { Freq } \\
(\mathrm{Hz})\end{array}$ & $\begin{array}{c}\text { Amp } \\
(\mathrm{p} . \mathrm{u})\end{array}$ & $\begin{array}{c}\text { Freq } \\
(\mathrm{Hz})\end{array}$ \\
\hline 0.2 & 250 & 0.16 & 250 & 0.2 & 250 \\
\hline 1.0 & 50 & 0.8 & 50 & 1.0 & 50 \\
\hline
\end{tabular}

\section{SinYAL MENGANDUNG TRANSIEN}

THH kemudian digunakan untuk menganalisis sinyal non- stasioner yang mengandung transien dan harmonisa $\mathrm{S}_{\mathrm{C}}(\mathrm{t})$ seperti pada (11) sbb:

$$
{ }_{C}(t)= \begin{cases}\sin \left(2 \pi 50 t_{a}\right)+0.2 \sin \left(2 \pi 250 t_{a}\right), & 0 \leq t_{a}<0.1 s \\ \sin \left(2 \pi 50 t_{b}\right)+0.2 \sin \left(2 \pi 250 t_{b}\right)+ & 0.1 \leq t_{b}<0.14 i \\ \sin \left(2 \pi 500 t_{b}\right) e^{\left(-30 t_{b}-0.1\right)}, & 0.14 \leq t_{c}<0.3 \\ \sin \left(2 \pi 50 t_{c}\right)+0.2 \sin \left(2 \pi 250 t_{c}\right)\end{cases}
$$

Sinyal transien tersebut ditunjukkan pada Gbr 7. FMI yang dihasilkan oleh proses DME dari sinyal $\mathrm{S}_{\mathrm{C}}(\mathrm{t})$ ditunjukkan pada Gbr 8. Adapun nilai sesaat dari amplitudo dan frekuensi yang diperoleh dari Transformasi Hilbert ditunjukkan pada Gbr 9.

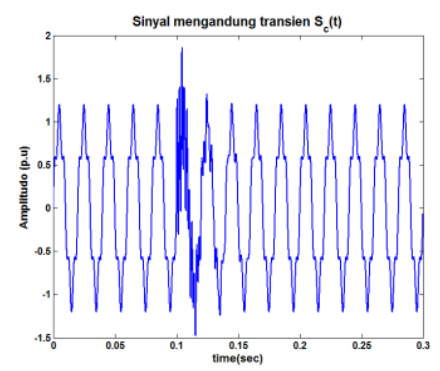

Gbr. 7 Sinyal mengandung transien $\mathrm{S}_{\mathrm{C}}(\mathrm{t})$

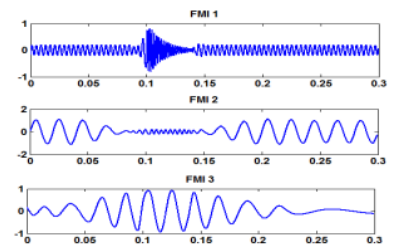

Gbr. 8 FMI dari sinyal $\mathrm{S}_{\mathrm{C}}(\mathrm{t})$

Nampak pada Gbr 9 bahwa THH dapat memperoleh nilai sesaat dari amplitudo dan frekuensi dari komponen komponen sinyal $\mathrm{S}_{\mathrm{C}}(\mathrm{t})$. Namun demikian, terdapat ketidak akuratan dikarenakan overshoot dan ambiguitas di sekitar perbatasan sinyal (diskontinuitas). Ketidak akuratan ini dapat diatasi dengan menggunakan teknik jendela untuk mendeteksi batas - batas segmen sebuah sinyal. Bila segmen sinyal telah diketahui, maka TH dapat digunakan pada sinyal tersebut sepanjang segmen yang teridentifikasi untuk memperoleh nilai sesaat dari amplitudo dan frekuensi. Hasil dari teknik jendela untuk sinyal $\mathrm{S}_{\mathrm{C}}(\mathrm{t})$ ditunjukkan pada Gbr 10 .

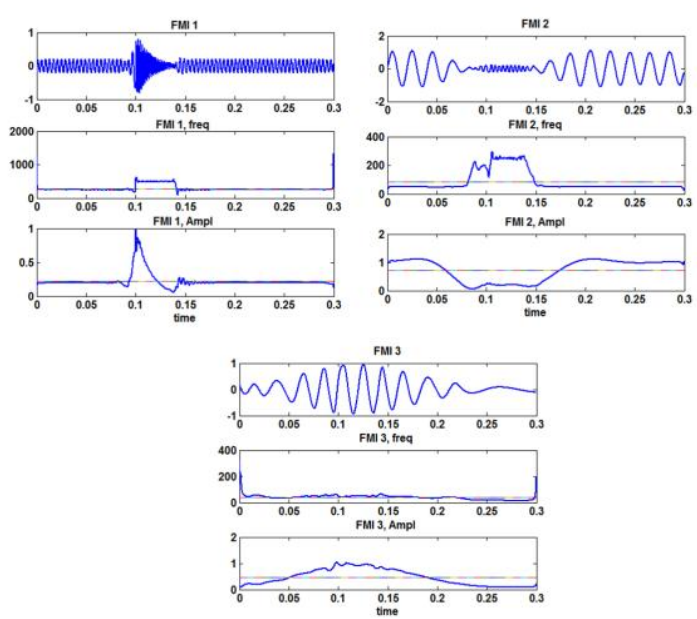

Gbr. 9 TH dari FMI sinyal SC(t)
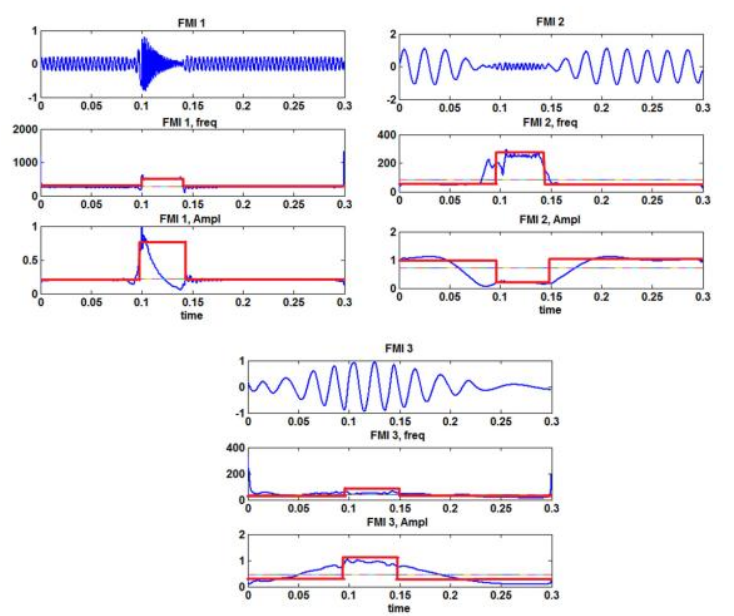

Gbr 10 Hasil Teknik jendela Terhadap plot TH dari FMI sinyal $\mathrm{S}_{\mathrm{C}}(\mathrm{t})$ 
VII. DETEKSI DAN KLASIFIKASI SINYAL

Dari beberapa sinyal yang mengandung masalah KD di atas, dapat dilihat bahwa THH dapat menguraikan komponen - komponen sinyal tersebut dalam bentuk FMI dengan baik. Jumlah FMI yang terdeteksi menunjukkan jumlah total komponen frekuensi termasuk frekuensi 50 $\mathrm{Hz}$ (fundamental) dan frekuensi tinggi (harmonisa). Dari setiap FMI tersebut dapat diperoleh plot amplitude dan frekuensi sesaat dengan menggunakan TH. Plot amplitudo dan frekuensi sesaat ini dapat digunakan sebagai fitur untuk melakukan identifikasi terhadap sinyal yang sedang dianalisa guna mengetahui kelas sinyal tersebut.

\section{A. Kelas Sinyal}

Dalam penelitian ini digunakan kelas - kelas sinyal non -stasioner sebagai berikut untuk mengidentifikasi sinyal - sinyal yang ditinjau.
C1 Normal
C2 Sag Murni
C3 Swell Murni
C4 Interupsi (pemadaman)
C5 Harmonisa
C6 Sag dengan Harmonisa
C7 Swell dengan Harmonisa
C8 Transien (peralihan).

\section{B. Metode Klasifikasi}

Alat klasifikasi yang digunakan dalam penelitian ini adalah Jaringan Saraf Tiruan (Artificial Neural Network) yang dapat mengenali pola - pola sinyal setelah mendapat serangkaian proses training (pembelajaran). Beberapa penelitian telah melaporkan penggunaan JST yang terbukti efektif dalam pengenalan pola sinyal yang mengandung masalah KD listrik $[11,12]$.

Gambar model Pengklasifikasi JST yang dirancang di sini ditunjukkan pada Gbr 11. Pengklasifikasi JST ini menerima masukan berupa sinyal listrik non - stasioner yang kemudian disegmentasi menggunakan teknik jendela. Setelah segmen diidentifikasi, sinyal per segmen diproses menggunakan DME yang menguraikan sinyal tersebut menjadi komponen - komponennya dalam bentuk FMI. TH kemudian memproses FMI tersebut untuk mendapatkan informasi amplitudo dan frekuensi sesaatnya. Jumlah total komponen yaitu komponen fundamental $(50 \mathrm{~Hz})$ ditambah komponen harmonisa pembentuk sinyal juga akan diketahui setelah proses dari THH tersebut.

Pemilihan fitur sinyal yang efisien memegang peranan yang sangat penting dalam keberhasilan proses identifikasi dan klasifikasi sinyal. Fitur sinyal yang dipilih hendaknya memiliki tingkat kemampuan yang tinggi untuk membedakan (separability) sinyal - sinyal yang diproses. [13]

Berdasarkan beberapa kali percobaan menggunakan JST dalam penelitian ini, fitur sinyal yang dipilih untuk melakukan proses klasifikasi sinyal adalah amplitudo sesaat dari FMI fundamental, frekuensi sesaat dari FMI1 dan jumlah komponen dari sinyal yang sedang diproses. Pemilihan ini dilakukan karena fitur tersebut dapat dengan baik membedakan bentuk sinyal dari kelas - kelas yang ditinjau. Informasi dari amplitudo sesaat sangat berguna untuk mengidentifikasi sinyal dari kelas sag, swell, interupsi, normal dan transien. Sedangkan informasi dari frekuensi sesaat sangat diperlukan untuk mengidentifikasi sinyal dari kelas transien. Informasi jumlah komponen sinyal digunakan untuk memastikan ada tidaknya komponen frekuensi harmonisa pada sinyal yang sedang diproses.

Fitur terpilih berupa amplitudo sesaat dari sinyal FMI fundamental dapat secara visual menunjukkan kelas sinyal yang diproses, sebagaimana ditunjukkan dalam Gbr 6(a) untuk sinyal sag. Sinyal swell, interupsi dan normal juga akan menunjukkan bentuk plot amplitudo sesaat yang spesifik dari sinyal FMI fundamental. Sedangkan komponen sinyal transien berfrekuensi tinggi yang biasanya muncul dalam waktu singkat akan mudah dikenali dengan melihat plot frekuensi sesaat dari FMI1 yang mengekstrak komponen frekuensi tinggi, seperti ditunjukkan oleh Gbr 10(a)

Dari informasi amplitudo sesaat, dipilih 9 titik yang mewakili untuk digunakan sebagai input JST Amplitudo, demikian juga untuk frekuensi sesaat, dipilih 9 titik sebagai input JST Frekuensi. Dengan demikian, terdapat 9 node input pada JST Amplitudo dan 9 node input pada JST Frekuensi. Masing - masing JST ini dilengkapi dengan hidden layer sejumlah 50 node dan ditraining secara terpisah menggunakan data amplitudo sesaat ataupun frekuensi sesaat.

Output layer dari JST amplitudo adalah sejumlah 4 neuron yang masing - masing mewakili kelas sinyal sag, swell, normal dan interupsi. Adapun pada output layer JST frekuensi terdapat satu neuron yang mengidentifikasi kandungan transien pada sinyal yang diproses. Ada tidaknya kandungan harmonisa ditunjukkan oleh jumlah komponen sinyal, bila nilainya lebih dari 1 berarti terdapat harmonisa pada sinyal tersebut.

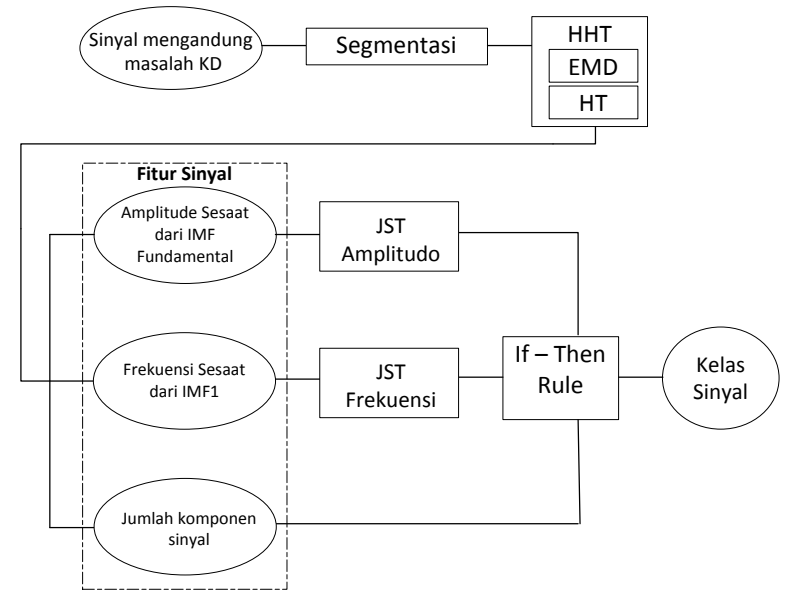

Gbr 11 Model Pengklasifikasi yang digunakan

Hasil identifikasi oleh JST Amplitudo, JST Frekuensi dan informasi jumlah komponen sinyal kemudian ditindaklanjuti oleh knowledge base yang akan menyimpulkan kelas sinyal yang sedang diproses. 


\section{HASIL PROSES DETEKSI DAN KLASIFIKASI}

Setiap JST ditraining dengan 75 data sinyal dari tiap klas dan 100 data dari tiap kelas digunakan sebagai testing. Hasil dari proses klasifikasi ditunjukkan pada Tabel 2. Elemen diagonal yang ditunjukkan dengan huruf tebal menyatakan sinyal KD yang diklasifikasikan dengan betul. Elemen off diagonal menyatakan klasifikasi yang salah. Secara keseluruhan, akurasi dari metode klasifikasi ini adalah sebesar $97,8 \%$.

Tabel 2

Hasil Klasifikasi sinyal mengandung masalah KD

\begin{tabular}{ccccccccc}
\hline & C1 & C2 & C3 & C4 & C5 & C6 & C7 & C8 \\
\hline C1 & 100 & 0 & 0 & 0 & 0 & 0 & 0 & 0 \\
\hline C2 & 1 & 95 & 4 & 0 & 0 & 0 & 0 & 0 \\
\hline C3 & 9 & 0 & 91 & 0 & 0 & 0 & 0 & 0 \\
\hline C4 & 1 & 0 & 0 & 99 & 0 & 0 & 0 & 0 \\
\hline C5 & 2 & 0 & 0 & 2 & 96 & 0 & 0 & 0 \\
\hline C6 & 1 & 0 & 0 & 2 & 0 & 97 & 0 & 0 \\
\hline C7 & 1 & 0 & 0 & 0 & 0 & 0 & 99 & 0 \\
\hline C8 & 0 & 0 & 0 & 0 & 0 & 0 & 0 & 100 \\
\hline
\end{tabular}

\section{KESIMPULAN}

Dalam makalah ini, metode $\mathrm{THH}$ telah digunakan untuk mengekstrak fitur efisien dari sinyal listrik yang mengandung masalah KD. Fitur yang dipilih adalah amplitudo sesaat dari FMI fundamental, frekuensi sesaat dari FMI 1 dan jumlah komponen sinyal. Fitur - fitur tersebut kemudian digunakan mentraining Jaringan Saraf Tiruan supaya dapat melakukan klasifikasi sinyal tersebut. Hasil klasifikasi memperlihatkan bahwa fitur yang dipilih telah dapat mengklasifikasi sinyal yang mengandung berbagai masalah KD dengan baik..

\section{UCAPAN TERIMA KASIH}

Penulis mengucapkan terima kasih kepada Menristek DIKTI yang telah menyediakan dukungan dana dalam penelitian ini.

\section{PUSTAKA}

[1] J. Dixit and A. Yadav, Electrical power quality: Laxmi Publications, Ltd., 2010.

[2] F. J. Harris, "On the use of windows for harmonic analysis with the discrete fourier transform," Proceedings of the IEEE, vol. 66, pp. 51-83, 1978.

[3] R. Flores, "Signal processing tools for power quality event classification," Lic.Eng. thesis, School Elect. Eng, Chalmers University of Technology, Gothenburg, Sweden, 2003.

[4] M. Misiti, "Wavelet Toolbox User's Guide, Version 1: For Use with MATLAB," ed: Math Works, 1996.

[5] W. G. Morsi and M. E. El-Hawary, "Suitable Mother Wavelet for Harmonics and Interharmonics Measurements Using Wavelet Packet Transform," Electrical and Computer Engineering, 2007. CCECE 2007.Canadian Conference on, pp. 748 - 752, 2007.

[6] N. E. Huang, Z. Shen, S. R. Long, M. C. Wu, H. H. Shih, Q. Zheng, N. C. Yen, C. C. Tung, and H. H. Liu, "The empirical mode decomposition and the hilbert spectrum for nonlinear and nonstationary time series analysis," Proceedings of the Royal Society A: Mathematical, Physical and Engineering Sciences, vol. 454, pp. 903-995, 1998.

[7] M. J. Afroni, D. Sutanto, and D. Stirling, "Analysis of NonStationary Power Quality Waveforms Using Iterative Hilbert Huang Transform and SAX Algorithm " IEEE Transactions on Power Delivery vol. 28, pp. 2134 - 2144, 2013
[8] G. Rilling, P. Flandrin, and P. Goncalves, "On empirical mode decomposition and its algorithms," in IEEE-EURASIP workshop on nonlinear signal and image processing, 2003, pp. 8-11.

[9] M. J. Afroni and D. Sutanto, "The Hilbert Huang transform for decomposition of power quality waveforms," in Power Engineering Conference (AUPEC), 2014 Australasian Universities, 2014, pp. 16.

[10] N. E. Huang, Z. Shen, S. R. Long, M. C. Wu, H. H. Shih, Q. Zheng, N. C. Yen, C. C. Tung, and H. H. Liu, "The empirical mode decomposition and the hilbert spectrum for nonlinear and nonstationary time series analysis," Proceedings of the Royal Society A: Mathematical, Physical and Engineering Sciences, vol. 454, pp. 903-995, March 1998

[11]S. Mishra, C. Bhende, and B. Panigrahi, "Detection and classification of power quality disturbances using S-transform and probabilistic neural network," IEEE Transactions On Power Delivery, vol. 23, pp. 280-287, 2008.

[12]N. Huang, D. Xu, X. Liu, and L. Lin, "Power quality disturbances classification based on S-transform and probabilistic neural network," Neurocomputing, vol. 98, pp. 12-23, 2012.

[13]M. Dash and H. Liu, "Feature selection for classification," Intelligent data analysis, vol. 1, pp. 131-156, 1997. 
